\title{
Challenging Giants. Hartree-Fock Methods Analysis Protonated Rhodochrosite Crystal and Potential in the Elimination of Cancer Cells Through Synchrotron Radiation
}

\author{
Ricardo Gobato*1, Marcia Regina Risso Gobato ${ }^{1}$, Alireza Heidari ${ }^{2}$ and Abhijit Mitra ${ }^{3}$ \\ ${ }^{1}$ Green Land Landscaping and Gardening, Seedling Growth Laboratory, Brazil \\ ${ }^{2}$ Faculty of Chemistry, California South University, USA
}

${ }^{3}$ Department of Marine Science, University of Calcutta, India

*Corresponding author: Ricardo Gobato, Green Land Landscaping and Gardening, Seedling Growth Laboratory, Brazil

\section{ARTICLE INFO \\ Received: 蔧 January 20, 2020

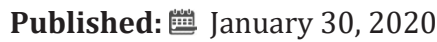 \\ Citation: Ricardo Gobato, Marcia Regina Risso Gobato, Alireza Heidari, Abhijit Mitra. Challenging Giants. Hartree-Fock Methods Analysis Protonated Rhodochrosite Crystal and Potential in the Elimination of Cancer Cells Through Synchrotron Radiation. Biomed J Sci \& Tech Res 25(1)-2020. BJSTR. MS.ID.004152.}

Abbreviations: UHF: Unrestricted Hartree-Fock ;APT: Atomic Polar Tensor ; CEP: Compact effective potentials; SAXS: Small-Angle X-Ray Scattering; USAXS: Ultra-Small Angle X-Ray Scattering; FXS: Fluctuation X-Ray Scattering; WAXS: Wide-Angle X-Ray Scattering; GISAXS: Grazing-Incidence Small-Angle X-Ray Scattering; GIWAXS: Grazing-Incidence Wide-Angle X-Ray Scattering; SANS: SmallAngle Neutron Scattering; GISANS: GrazingIncidence Small-Angle Neutron Scattering; XRD: X-Ray Diffraction; PXRD: Powder X-Ray Diffraction; WAXD: Wide-Angle X-Ray Diffraction; GIXD: Grazing- Incidence X-Ray Diffraction; EDXRD: Energy-Dispersive X-Ray Diffraction

\begin{abstract}
The rhodochrosite $\left(\mathrm{MnCO}_{3}\right)$ shows complete solid solution with siderite $\left(\mathrm{FeCO}_{3}\right)$, and it may contain substantial amounts of $\mathrm{Zn}, \mathrm{Mg}$, $\mathrm{Co}$, and $\mathrm{Ca}$. There is no precedent in the literature on the treatment of tumor tissues by eliminating these affected tissues, using rhodocrosite crystals in tissue absorption and eliminating cancerous tissues by synchrotron radiation. The studies that are found are the research papers of this team. Through an unrestricted HartreeFock (UHF) computational simulation, Compact effective potentials (CEP), the infrared spectrum of the protonated rhodochrosite crystal, $\mathrm{CH}_{19} \mathrm{Mn}_{6} \mathrm{O}_{8}$, and the load distribution by the unit molecule by two widely used methods, Atomic Polar Tensor (APT) and Mulliken, were studied. The rhodochrosite crystal unit cell of structure $\mathrm{CMn}_{6} \mathrm{O}_{8}$, where the load distribution by the molecule was verified in the UHF CEP-4G (Effective core potential (ECP) minimal basis), UHF CEP-31G (ECP split valance) and UHF CEP-121G (ECP triple-split basis). The largest load variation in the APT and Mulliken methods were obtained in the CEP-121G basis set, with $\delta=$ 2.922 e $\delta=2.650 \mathrm{u}$. a., respectively, being $\delta_{\mathrm{APT}}>\delta_{\text {Mulliken }}$. The maximum absorbance peaks in the CEP-4G, CEP-31G and CEP-121G basis set are present at the frequencies $2172.23 \mathrm{~cm}^{-1}$, with a normalized intensity of $0.65 ; 2231.4 \mathrm{~cm}^{-1}$ and 0.454 ; and $2177.24 \mathrm{~cm}^{-1}$ and 1.0 , respectively. An in-depth study is necessary to verify the absorption by the tumoral and non-tumoral tissues of rhodochrosite, before and after irradiating of synchrotron radiation using Small-Angle X-Ray Scattering (SAXS), Ultra-Small Angle X-Ray Scattering (USAXS), Fluctuation X-Ray Scattering (FXS), Wide-Angle X-Ray Scattering (WAXS), Grazing-Incidence Small-Angle X-Ray Scattering (GISAXS), Grazing-Incidence Wide-Angle X-Ray Scattering (GIWAXS), Small-Angle Neutron Scattering (SANS), Grazing-Incidence Small-Angle Neutron Scattering (GISANS), X-Ray Diffraction (XRD), Powder X-Ray Diffraction (PXRD), Wide-Angle X-Ray Diffraction (WAXD), Grazing- Incidence X-Ray Diffraction (GIXD) and Energy-Dispersive X-Ray Diffraction (EDXRD). Later studies could check the advantages and disadvantages of rhodochrosite in the treatment of cancer through synchrotron radiation, such as one oscillator crystal. Studying the sites of rhodocrosite action may lead to a better understanding of its absorption by healthy and/or tumor tissues, thus leading to a better application of synchrotron radiation to the tumors to eliminate them.
\end{abstract}

Keywords: Rhodochrosite; Quartz Crystal; Hartree-Fock Methods; APT; Mulliken; Effective Core Potential; Synchrotron Radiation; Cancer; Tumoral Tissues 


\section{Introduction}

The rhodochrosite $\left(\mathrm{MnCO}_{3}\right)$ shows complete solid solution with siderite $\left(\mathrm{FeCO}_{3}\right)$, and it may contain substantial amounts of $\mathrm{Zn}, \mathrm{Mg}$, Co, and Ca. The electric charge that accumulates in certain solid materials, such as crystals, certain ceramics, and biological matter such as bone, DNA and various proteins in response to applied mechanical stress, phenomenon called piezoelectricity [1-12]. Through an unrestricted Hartree-Fock (UHF) computational simulation, Compact effective potentials (CEP), the infrared spectrum of the protonated rhodochrosite crystal, $\mathrm{CH}_{19} \mathrm{Mn}_{6} \mathrm{O}_{8^{\prime}}$ and the load distribution by the unit molecule by two widely used methods, Atomic Polar Tensor (APT) and Mulliken, were studied. The rhodochrosite crystal unit cell of structure $\mathrm{CMn}_{6} \mathrm{O}_{8}$, where the load distribution by the molecule was verified in the UHF CEP-4G (Effective core potential (ECP) minimal basis), UHF CEP-31G (ECP split valance) and UHF CEP-121G (ECP triple-split basis). The Figures 1 \& 2 is one photography the Rhodochrosite stone, some cut and used with semi-precious jewelry. The lovely rose-pink rock, Rhodochrosite, like its namesake the rose, is soft and fragile, measuring only 3.5 to 4 on the hardness, or Mohs scale. It is found in two forms: the first is a clear, bright pink, rhombohedra, gem quality crystal, which is rare and demands great skill from the cutter. The more common form, which comes from white banded stalactite rocks, is a little harder and is used for semi-precious jewelry [14].
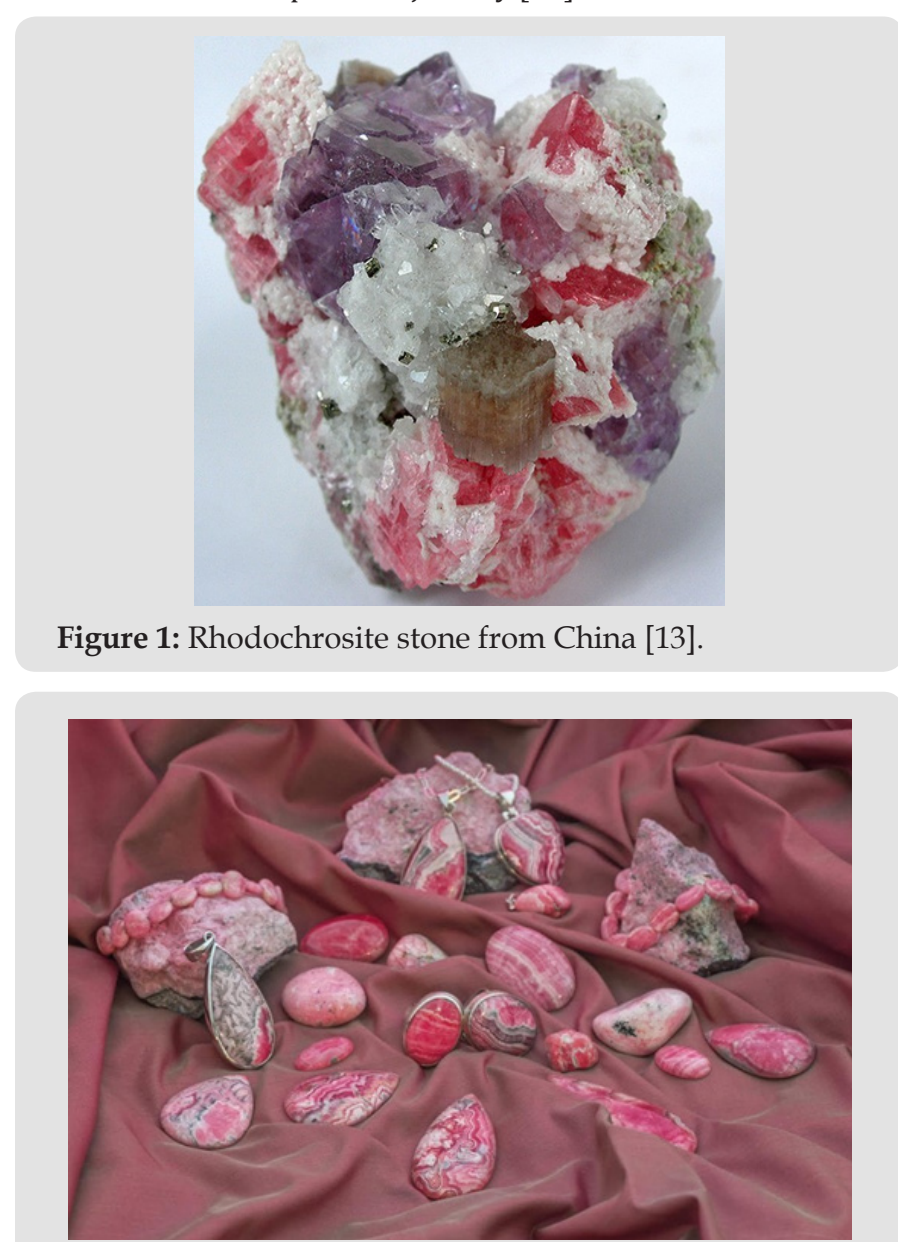

Figure 1: Some natural rhodochrosite rocks and others whipped and used with semi precious jewels [14].

\section{Methods}

\section{Hartree-Fock Methods}

The molecular Hartree-Fock [15-21] wave function is written as an antisymmetrized product (Slater determinant) of spin-orbitals, each spin-orbital being a product of a spatial orbital $\phi_{i}$ and a spin function (either $\alpha$ or $\beta$ ) [22-31].

The expression for the Hartree-Fock molecular electronic energy $E_{H F}$ is given by the variation theorem as $E_{H F}=\left\langle D\left|\hat{H}_{\mathrm{el}}+V_{N \mathrm{NV}}\right| D\right\rangle$ where D is the Slater-determinant Hartree-Fock wave function and $\hat{H}_{c 1}$ and $V_{N N}$ are given by

$$
\begin{array}{r}
\hat{H}_{e 1}=-\frac{h^{2}}{2 m_{e}} \sum_{i} \nabla_{i}^{2}-\sum_{\alpha} \sum_{i} \frac{Z_{\alpha} e^{\prime 2}}{r_{i \alpha}}+\sum_{j} \sum_{i>j} \frac{e^{\prime 2}}{r_{i j}} \\
V_{N N}=\sum_{\alpha} \sum_{\beta>\alpha} \frac{Z_{\alpha} Z_{\beta} e^{\prime 2}}{r_{\alpha \beta}}
\end{array}
$$

Since $V_{\mathrm{NN}}$ does not involve electronic coordinates and $\boldsymbol{D}$ is normalized, we have $\left\langle D\left|V_{N N}\right| D\right\rangle=V_{N N}\langle D \mid D\rangle=V_{N N}$. The operator $\hat{H}_{e \mathrm{i}}$ is the sum of one-electron operators $\hat{f}_{i}$ and two-electron operators $\hat{g_{i j}}$; we have $\hat{H}_{e 1} \sum_{i} \hat{f}_{i}+\sum_{j} \sum_{i>j} \hat{g_{i j}}$, where $\hat{f}_{i}=\frac{1}{2} \nabla_{i}^{2} \sum_{\alpha} \sum_{\alpha} / r_{i \alpha}$ and $\hat{g_{i j}}=1 / r_{i j}$. The Hamiltonian $\hat{H}_{\text {el }}$ is the same as the Hamiltonian $\hat{H}$ for an atom except that $\sum_{\alpha} \sum_{\alpha} / r_{i \alpha}$ replaces $Z / r_{i}$ in $\hat{f}_{i}$. Hence

$$
E=\langle D|H| \hat{D}\rangle=2 \sum_{i}^{n / 2}\left\langle\phi_{i}(1)\left|\hat{f}_{i}\right| \phi_{i}(2)\right\rangle+\sum_{j=1}^{n / 2} \sum_{i=1}^{n / 2}\left(2 J_{i j}-K_{i j}\right)
$$

where

$$
J_{i j}=\left\langle\phi_{i}(1) \phi_{j}(2)\left|e^{\prime 2} / r_{12}\right| \phi_{i}(1) \phi_{j}(2)\right\rangle
$$

and

$$
\begin{gathered}
K_{i j}=\left\langle\phi_{i}(1) \phi_{j}(2)\left|e^{\prime 2} / r_{12}\right| \phi_{j}(1) \phi_{i}(2)\right\rangle \\
\hat{f}_{i}=-\left(h^{2} / 2 m_{e}\right) \nabla_{i}^{2}-Z e^{\prime 2} / r_{1}
\end{gathered}
$$

can be used to give $\left\langle D \mid H_{e 1} \hat{\mid} D\right\rangle$.

Therefore, the Hartree-Fock energy of a diatomic or polyatomic molecule with only closed shells is

$$
\begin{gathered}
E_{H F}=2 \sum_{i=1}^{n / 2} H_{i}^{\text {core }}+\sum_{j=1}^{n / 2} \sum_{i=1}^{n / 2}\left(2 J_{i j}-K_{i j}\right)+V_{N N} \\
H_{i}^{\text {core }} \equiv\left\langle\phi_{i}(1)\left|H^{\text {core }}(1)\right|+\phi_{i}(1)\right\rangle \equiv\left\langle\phi_{i}(1)\left|-\frac{1}{2} \nabla_{i}^{2} \sum_{\alpha} Z_{\alpha} / r_{1 \alpha}\right| \phi_{i}(1) \mid\right\rangle \\
J_{i j}=\left\langle\phi_{i}(1) \phi_{j}(2)\left|1 / r_{12}\right| \phi_{i}(1) \phi_{j}(2)\right\rangle
\end{gathered}
$$

and

$$
K_{i j}=\left\langle\phi_{i}(1) \phi_{j}(2)\left|1 / r_{12}\right| \phi_{j}(1) \phi_{i}(2)\right\rangle
$$

where the one-electron-operator symbol was changed from $\hat{f}_{i}$ to $H^{\hat{\text { cor }}}(1)$. [5]

\section{Result}

The Figure 3 show on cell structure of a protonated rhodochrosite crystal of structureStoichiometric is $\mathrm{CH}_{19} \mathrm{Mn}_{6} \mathrm{O}_{8}$, obtained after molecular dynamics via unrestricted Hartree-Fock method, in basis set CEP-4G, CEP-31G and CEP-121G [32-97].The rhodochrosite crystal unit cell of structure CMn608, where the load distribution by the molecule was verified in the unrestricted Hartree-Fock method, UHF CEP-4G (Effective core potential (ECP) minimal basis), UHF CEP-31G (ECP split valance) and UHF CEP-121G (ECP triple-split basis), through the analysis of APT and Mulliken 
loads [98-100].The rhodochrosite unit cell was protonated, then presented the structure CH19Mn608 for the study with ab initio methods with +4 multiplicity. The displacement of charges by the molecule was analyzed to verify the site of molecular action. The load distribution by the protonated crystal is evaluated in Table 1, and its vibrational frequencies in Table 2 . The largest load variation in the APT and Mulliken methods were obtained in the CEP-121G base set, with $\delta=2.922$ e $\delta=2.650$, respectively, being $\delta_{\mathrm{APT}}>$ $\delta_{\text {Mulliken }}$, in all sets of calculated bases, Table 1 . The Table 2 show the maximum absorbance peaks in the CEP-4G, CEP-31G and CEP$121 \mathrm{G}$ set basis are present at the frequencies $2172.23 \mathrm{~cm}-1$, with a normalized intensity of $65 \%$; $2231.4 \mathrm{~cm}-1$ and $45.4 \%$; and 2177.24 $\mathrm{cm}^{-1}$ and $100 \%$, respectively.

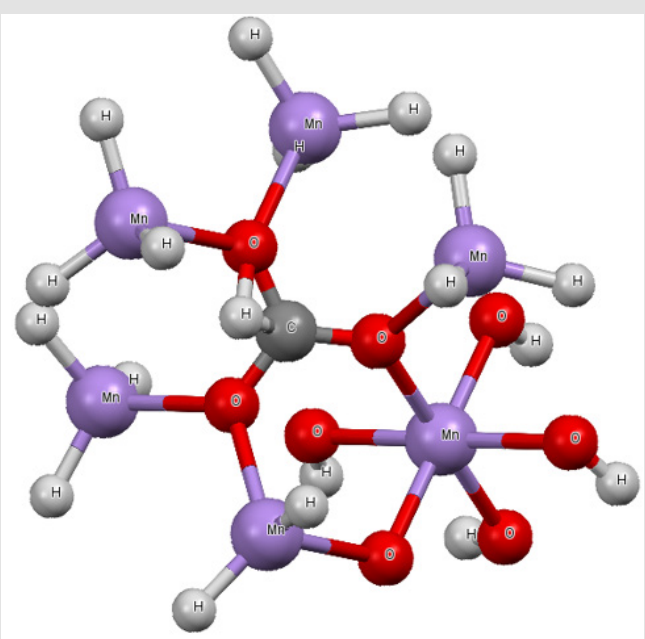

Figure 3: Cell structure of a protonated rhodochrosite crystal. Represented in red the oxygen; Purple in color Manganese; in gray color Hydrogen; in dark grey color the Carbon. Stoichiometry: $\mathrm{CMn}_{6} \mathrm{O}_{8}$. Stoichiometry protonated: $\mathrm{CH}_{19} \mathrm{Mn}_{6} \mathrm{O}_{8}$.

Table 1: Load shifting on given basis sets of the Mulliken and APT method.

\begin{tabular}{|c|c|c|c|c|c|c|}
\hline Basis Sets & \multicolumn{3}{|c|}{ Mulliken } & \multicolumn{3}{c|}{ APT } \\
\hline & Charge* & & $\boldsymbol{\delta}$ & & Charge* $^{*}$ & $\boldsymbol{\delta}$ \\
\hline CEP-4G & -1.064 & 1.064 & 2.128 & -1.366 & 1.366 & 2.732 \\
\hline CEP-31G & -1.034 & 1.034 & 2.068 & -1.362 & 1.362 & 2.724 \\
\hline CEP-121G & -1.325 & 1.325 & 2.65 & -1.461 & 1.461 & 2.922 \\
\hline
\end{tabular}

\section{Analysis}

The Mulliken load method in the UHF-CEP-4G base set; UHFCEP-31G and UHF-CEP-121G are sufficient to show that the sites of action of the rhodochrosite crystal structure are found in three Oxygen-linked Manganese atoms, which are attached to the central Carbon atom, as well as these. Oxygen atoms and the central Carbon. The charge displacement is strong in the oxygen atoms, especially those near the central carbon, with negative load in all set basis studied, both in the APT and Mulliken charges. The central carbon atom on all set basis is positively charged in both APT and Mulliken load, except Milliken in CEP-31G, which is neutral. As might be expected from the charges by APT, the strong positive load manganese atoms, the strong negative load oxygen, the positively charged carbon atom. The manganese atom farthest from the carbon atom has a slight positive to neutral load shift. The Mulliken load method presents a better result when compared to the APT, in the studied set basis, for protonated rhodochrosite crystal, with a smaller load variation $\delta=2,650$ u.a for CEP-121G.

The absorption peaks are in a Gaussian between the frequencies $1620 \mathrm{~cm}^{-1}$ and $2520 \mathrm{~cm}^{-1}$, Figure 3.The largest load variation in the APT and Mulliken methods were obtained in the CEP-121G base set, with $\delta=2.922$ e $\delta=2.650$, respectively, being $\delta_{\mathrm{APT}}>\delta_{\text {Mulliken }}$, in all sets of calculated basis, Table 1 . The Figure 1 is one photography the Rhodochrosite stone from China. The Figure 2 is one photography the Rhodochrosite stone, some cut and used with semi-precious jewelry. The Figure 3 represented a Cell structure of a protonated rhodochrosite crystal. Represented in red the oxygen; silver in color Manganese; in gray color Hydrogen; in light see green color the Carbon. Stoichiometry not protonated: $\mathrm{CMn}_{6} \mathrm{O}_{8}$. Stoichiometry protonated: $\mathrm{CH}_{19} \mathrm{Mn}_{6} \mathrm{O}_{8}$. The Figure 3 show the protonated rhodochrosite crystal for UHF-CEP-4G basis set, UHF-CEP-31G and UHF-CEP-121G, respectively, which are shown in Table 2. The rhodochrosite crystal unit cell of structure $\mathrm{CMn}_{6} \mathrm{O}_{8^{\prime}}$ where the load distribution by the molecule was verified in the unrestricted Hartree-Fock method, UHF CEP-4G (Effective core potential (ECP) minimal basis), UHF CEP-31G (ECP split valance) and UHF CEP-121G (ECP triple-split basis), through the analysis of APT and Mulliken loads.

Note: * $\pm 1,602176634 \times 10^{-19} \mathrm{C}($ Coulomb)

Table 2: Peaks maximum absorption intensity by the frequency given. Absorbance frequency as a function of vibrational frequencies of protonated rhodochrosite crystal for UHF-CEP-4G basis set, UHF-CEP-31G and UHF-CEP-121G.

\begin{tabular}{|c|c|c|c|c|c|c|c|c|}
\hline \multicolumn{2}{|c|}{$v\left(\mathrm{~cm}^{-1}\right)$} & I (\%) & $v\left(\mathrm{~cm}^{-1}\right)$ & I (\%) & $v\left(\mathrm{~cm}^{-1}\right)$ & I (\%) & $v\left(\mathrm{~cm}^{-1}\right)$ & I (\%) \\
\hline CEP-4G & 2172.23 & 64.9904 & 2043.25 & 51.7671 & 2193.1 & 41.6608 & 2242.97 & 36.4643 \\
\hline CEP-31G & 2231.4 & 45.3589 & 1891.26 & 41.6207 & 2027.77 & 40.3978 & 1926.32 & 38.0064 \\
\hline CEP-121G & 2177.24 & 100 & 2261.98 & 87.0553 & 1947.03 & 83.1151 & 1778.57 & 51.6624 \\
\hline
\end{tabular}

Note: $\mathrm{v}=$ Frequency $\left(\mathrm{cm}^{-1}\right) ; \mathrm{I}=$ Normalized Intensity $(\%)$. 


\section{Conclusion}

The absorption peaks are in a Gaussian between the frequencies $1620 \mathrm{~cm}^{-1}$ and $2520 \mathrm{~cm}^{-1}$. The Mulliken load method presents a better result when compared to the APT, in the studied set basis, for protonated rhodochrosite crystal, with a smaller load variation $\delta=2,650$ u.a for CEP-121G.The maximum absorbance peaks in the CEP-4G, CEP-31G and CEP-121G basis set are present at the frequencies $2172.23 \mathrm{~cm}^{-1}$, with a normalized intensity of $0.65 ; 2231.4 \mathrm{~cm}^{-1}$ and 0.454; and $2177.24 \mathrm{~cm}^{-1}$ and 1.0, respectively. Later studies could check the advantages and disadvantages of rhodochrosite in the treatment of cancer through synchrotron radiation, such as one oscillator crystal. An in-depth study is necessary to verify the absorption by the tumoral and non-tumoral tissues of rhodochrosite, before and after irradiating of synchrotron radiation using Small-Angle X-Ray Scattering (SAXS), Ultra-Small Angle X-Ray Scattering (USAXS), Fluctuation X-Ray Scattering (FXS), Wide-Angle X-Ray Scattering (WAXS), Grazing-Incidence Small-Angle X-Ray Scattering (GISAXS), Grazing-Incidence Wide-Angle X-Ray Scattering (GIWAXS), SmallAngle Neutron Scattering (SANS), Grazing-Incidence Small-Angle Neutron Scattering (GISANS), X-Ray Diffraction (XRD), Powder X-Ray Diffraction (PXRD), Wide-Angle X-Ray Diffraction (WAXD), Grazing-Incidence X-Ray Diffraction (GIXD) and Energy-Dispersive X-Ray Diffraction (EDXRD).

\section{Disclosures/Conflict of interest}

The authors declare that there is no conflict of interest.

\section{References}

1. James Holler F, Douglas A Skoog, Stanley R (2020) Crouch. Principles of Instrumental Analysis $6^{\text {th }}$ (Edn.), Cengage Learning p. 9.

2. Fox Electronics (2008) Quartz Crystal Theory of Operation and Design Notes. Oscillator Theory of Operation and Design Notes. 2008.

3. Newnham RE (2005) Properties of materials. Anisotropy, Simmetry, Structure. Oxford University Press, New York, USA.

4. Gribble CD, Hall AJ (1985) A Practical Introduction to Optical Mineralogy.

5. Creative Commons (CC-BY 4.0). Wikipedia, The Free Encyclopedia, May 2019.

6. Ricardo Gobato, Marcia Regina Risso Gobato, Alireza Heidari (2019) Rhodochrosite as Crystal Oscillator. Am J Biomed Sci \& Res 3 (2).

7. Ricardo Gobato, Marcia Regina Risso Gobato, Alireza Heidari (2019) Calculation by UFF method of frequencies and vibrational temperatures of the unit cell of the rhodochrosite crystal International Journal of Advanced Chemistry 7 (2): 77-81.

8. Ricardo Gobato, Marcia Regina Risso Gobato, Alireza Heidari (2019) Rhodochrosite as Crystal Oscillator.

9. Ricardo Gobato, Marcia Regina Risso Gobato, Alireza Heidari (2019) Rhodochrosite as Crystal Oscillator. Am J Biomed Sci \& Res 3(2).

10. Ricardo Gobato, Marcia Regina Risso Gobato, Alireza Heidari. Rhodochrosite as Crystal Oscillator. viXra.org, Condensed Matter, viXra: 1908. 0295.

11. Ricardo Gobato, Marcia Regina Risso Gobato, Alireza Heidari, Abhijit Mitra (2019) Rhodochrosite Optical Indicatrix. Peer Res Nest 1 (3).

12. Ricardo Gobato, Marcia Regina Risso Gobato, Alireza Heidari, Abhijit Mitra. Rhodochrosite Optical Indicatrix. viXra.org > Condensed Matter > viXra: 1908. 0455 .
13. (2010) Rob Lavinsky, iRocks.com, CC-BY-SA-3.0.

14. (2019) Gemstone Qualities. Rhodochrosite. 2019.

15. Levine IN (2003) Quantum Chemistry, 5th (Edn.), Pearson Education (Singapore) Pte. Ltd., Indian Branch, 482 F. I. E. Patparganj, Delhi 110 092, India.

16. Szabo A, Ostlund NS (1989) Modern Quantum Chemistry. Dover Publications, New York, USA.

17. Gordon MS, Michael W Schmidt, Kim K Baldridge, Jerry A Boatz, Steven T Elbert, et al. (1993) General atomic and molecular electronic structure system (GAMESS). J. Comput. Chem 14: 1347-1363.

18. Ohno K, Esfarjani K, Kawazoe Y (1999) Computational Material Science. Springer-Verlag, Berlin, Germany.

19. Wolfram K, Hothausen MC (2001) Introduction to DFT for Chemists, $2^{\text {nd }}$ (Edn.), John Wiley \& Sons, Inc. New York, USA.

20. Hohenberg P,Kohn W (1964) Inhomogeneous electron gas. Phys Rev (136): B864-B871.

21. Kohn W, Sham LJ (1965) Self-consistent equations including exchange and correlation effects. Phys Rev (140): A1133.

22. Mulliken (1955) J Chem Phys 23: 1833-1840.

23. Csizmadia IG (1976) Theory and Practice of MO Calculations on Organic Molecules, Elsevier, Amsterdam, Netherlands.

24. Ferreira MMC (1990) Partition of the Dipole Moment and Atomic Polar Tensor: The Water Molecule".J Phys Chem 94: 3220-3223.

25. Biarge JF, Herranz J, Morcillo J (1961) An R Soc Esp Fis Quim Ser A: A57, 81.

26. Person WB, Newton JH (1974) J Chem Phys 61: 1040.

27. King WT, Mast GB (1976) J Phys Chem 80: 2521.

28. King WT (1982) Vibrational Intensities in Infrared and Ramon Spectra: Person WB, Zerbi G (Eds.), Elsevier, Amsterdam, Chapter 6.

29. Person WB, Zilles B. Rogers JD, Maia RGA (1982) J Mol Struct80: 297.

30. Zilles BA (1980) Dissertation, University of Florida, USA.

31. Zilles BA, Person W (1983) J Chem Phys 79: 65.

32. Ricardo Gobato, Marcia Regina Risso Gobato, Alireza Heidari, Abhijit Mitra (2019) Hartree-fock Methods Analysis Protonated Rhodochrosite Crystal and Potential in the Elimination of Cancer Cells Through Synchrotron Radiation. Radiation Science and Technology 5(3): pp. 27 36.

33. Ricardo Gobato, Ibtihal Kadhim Kareem Dosh, Alireza Heidari, Abhijit Mitra, et al. (2019) Perspectives on the Elimination of Cancer Cells Using Rhodochrosite Crystal Through Synchrotron Radiation, and Absorption the Tumoral and Non-Tumoral Tissues. Arch Biomed Eng \& Biotechnol. 3(2): ABEB.MS.ID.000558.

34. Gordon MS, Schmidt MW (2005) Advances in electronic structure theory: GAMESS a decade later. Theory and Applications of Computational Chemistry: the first forty years, Elsevier, CE Dykstra, G Frenking, KS Kim, GE Scuseria (Eds.), Amsterdam, Netherlands, pp: 1167-1189.

35. GobatoR, Gobato A, Fedrigo DFG (2014) Inorganic arrangement crystal beryllium, lithium, selenium and silicon. In XIX Semana da Física. Simpósio Comemorativo dos 40 anos do Curso de Física da Universidade Estadual de Londrina, Brazil, 2014. Universidade Estadual de Londrina (UEL), Brazil.

36. Gobato R (2008) Benzocaína, um estudo computacional, Master's thesis, Universidade Estadual de Londrina (UEL), Brazil.

37. Gobato R (2017) Study of the molecular geometry of Caramboxin toxin found in star flower (Averrhoa carambola L.). Parana J Sci Edu 3 (1): 1-9.

38. Gobato R, Gobato A, Fedrigo DFG (2015) Molecular electrostatic potential of the main monoterpenoids compounds found in oil Lemon Tahiti-(Citrus Latifolia Var Tahiti). Parana J Sci Edu 1 (1): 1-10. 
39. Gobato R, Fedrigo DFG, Gobato A (2015) Allocryptopine, Berberine Chelerythrine, Copsitine, Dihydrosanguinarine, Protopine and Sanguinarine. Molecular geometry of the main alkaloids found in the seeds of Argemone Mexicana Linn. Parana J Sci Edu 1 (2): 7-16.

40. Gobato R, Heidari A (2018) Infrared Spectrum and Sites of Action of Sanguinarine by Molecular Mechanics and ab initio Methods. International Journal of Atmospheric and Oceanic Sciences 2(1): 1-9.

41. Gobato R, Fedrigo DFG, Gobato A (2015) Molecular geometry of alkaloids present in seeds of mexican prickly poppy. Cornell University Library. Quantitative Biology 1507:05042.

42. Gobato R, Gobato A, Fedrigo DFG (2016) Study of the molecular electrostatic potential of D-Pinitol an active hypoglycemic principle found in Spring flower Three Marys (Bougainvillea species) in the $\mathrm{Mm}+$ method. Parana J Sci Educ 2 (4): 1-9.

43. Gobato R, Fedrigo DFG, Gobato A (2015) Avro: key component of Lockheed X-35. Parana J Sci Educ 1 (2): 1-6.

44. Gobato R, Fedrigo DFG, Gobato A (2016) LOT-G3: Plasma Lamp, Ozonator and CW Transmitter. Ciencia e Natura: 38 (1).

45. Gobato R (2016) Matter and energy in a non-relativistic approach amongst the mustard seed and the faith. A metaphysical conclusion. Parana J Sci Educ 2 (3): 1-14.

46. Gobato R, Gobato A, Fedrigo DFG (2016) Harnessing the energy of ocean surface waves by Pelamis System. Parana J Sci Edu 2(2): 1-15.

47. Gobato R, Gobato a, Fedrigo (2016) Mathematics for input space probes in the atmosphere of Gliese 581d. Parana J Sci Educ 2(5): 6-13.

48. Gobato R, Gobato A, Fedrigo DFG (2016) Study of tornadoes that have reached the state of Parana. Parana J Sci Educ 2(1): 1-27.

49. Gobato R, Simões MF (2017) Alternative Method of RGB Channel Spectroscopy Using a CCD Reader. Ciencia e Natura 39 (2).

50. Gobato R, Heidari A (2017) Calculations Using Quantum Chemistry for Inorganic Molecule Simulation BeLi2SeSi. Science Journal of Analytical Chemistry 5(5): 76-85.

51. Gobato MRR, Gobato R, Heidari A (2018) Planting of Jaboticaba Trees for Landscape Repair of Degraded Area. Landscape Architecture and Regional Planning 3(1): 1-9.

52. Gobato R (2012) The Liotropic Indicatrix, 2012,114 p. Thesis (Doctorate in Pysics). Universidade Estadual de Londrina, Londrina.

53. Gobato R, Heidari A (2017) Calculations Using Quantum Chemistry for Inorganic Molecule Simulation BeLi2SeSi. Science Journal of Analytical Chemistry 5(6):76-85.

54. Gobato R (2009) O universo dos cristais líquidos. Cadernos PDE, Secretaria de Estado da Educação do Paraná, 2: 1-15.

55. Gobato R, Heidari A (2018) Molecular Mechanics and Quantum Chemical Study on Sites of Action of Sanguinarine Using Vibrational Spectroscopy Based on Molecular Mechanics and Quantum Chemical Calculations. Malaysian Journal of Chemistry 20(1): 1-23.

56. Heidari A, Gobato R(2018) A Novel Approach to Reduce Toxicities and to Improve Bioavailabilities of DNA/RNA of Human Cancer Cells-Containing Cocaine (Coke), Lysergide (Lysergic Acid Diethyl Amide or LSD), $\Delta 9_{-}$ Tetrahydrocannabinol (THC) [(-)-trans- $\Delta$ 9-Tetrahydrocannabinol], Theobromine (Xantheose), Caffeine, Aspartame (APM) (NutraSweet) and Zidovudine (ZDV) [Azidothymidine (AZT)] as Anti-Cancer Nano Drugs by Coassembly of Dual Anti-Cancer Nano Drugs to Inhibit DNA/ RNA of Human Cancer Cells Drug Resistance. Parana Journal of Science and Education 4(6): 1-17.

57. Heidari A, Gobato R (2018) Ultraviolet Photoelectron Spectroscopy (UPS) and Ultraviolet-Visible (UV-Vis) Spectroscopy Comparative Study on Malignant and Benign Human Cancer Cells and Tissues with the Passage of Time under Synchrotron Radiation. Parana Journal of Science and Education 4(6): 18-33.
58. Gobato R, Heidari A (2018) Using the Quantum Chemistry for Genesis of a Nano Biomembrane with a Combination of the Elements $\mathrm{Be}, \mathrm{Li}, \mathrm{Se}, \mathrm{Si}, \mathrm{C}$ and H. J Nanomed Res 7(4): 241-252.

59. Agarwal SK, Roy S, Pramanick P, Mitra P, Gobato R, et al. (2018) Marsilea quadrifolia: A floral species with unique medicinal properties. Parana J Sci Educ 4(5): 15-20.

60. Mitra A, Zaman S, Gobato R (2018) Indian Sundarban Mangroves: A potential Carbon Scrubbing System. Parana J Sci Educ 4(4): (7-29).

61. Yarman 0, Gobato R, Yarman T, Arik M (2018) A new Physical constant from the ratio of the reciprocal of the "Rydberg constant" to the Planck length. Parana J Sci Educ 4(3): (42-51).

62. Gobato R, Simões MF (2017) Alternative Method of Spectroscopy of Alkali Metal RGB. Modern Chemistry 5(4): 70-74.

63. Fedrigo DFG, Gobato R, Gobato (2015) "Avrocar: a real flying saucer", Cornell University Library. arXiv: 1507.06916v1.

64. Simões MF, Palangana AJ, Gobato R, Santos OR (2012) Micellar shape anisotropy and optical indicatrix in reentrant isotropic-nematic phase transitions. The Journal of Chemical Physics 137: 204905.

65. Heidari A, Gobato R (2018) Putrescine, Cadaverine, Spermine and Spermidine-Enhanced Precatalyst Preparation Stabilization and Initiation (EPPSI) Nano Molecules. Parana Journal of Science and Education (PJSE)-v 4(5): 1-14.

66. Gobato R, Heidari A, Mitra A (2018) The Creation of C13H20BeLi2SeSi. The Proposal of a Bio-Inorganic Molecule, Using Ab Initio Methods for the Genesis of a Nano Membrane. Arc Org Inorg Chem Sci 3 (4).

67. Gobato R, Heidari A, Mitra A (2018) Using the Quantum Chemistry for Genesis of a Nano Biomembrane with a Combination of the Elements Be, $\mathrm{Li}, \mathrm{Se}, \mathrm{Si}, \mathrm{C}$ and H. ResearchGate.

68. Heidari A, GobatoR( 2018) First-Time Simulation of Deoxyuridine Monophosphate (dUMP) (Deoxyuridylic Acid or Deoxyuridylate) and Vomitoxin (Deoxynivalenol (DON)) ( $(3 \alpha, 7 \alpha)-3,7,15-T r i h y d r o x y-12,13$ Epoxytrichothec-9-En-8-One)-Enhanced Precatalyst Preparation Stabilization and Initiation (EPPSI) Nano Molecules Incorporation into the Nano Polymeric Matrix (NPM) by Immersion of the Nano Polymeric Modified Electrode (NPME) as Molecular Enzymes and Drug Targets for Human Cancer Cells, Tissues and Tumors Treatment under Synchrotron and Synchrocyclotron Radiations. Parana Journal of Science and Education 4(6) 46-67.

69. Gobato R, Gobato MRR, Heidari A, Mitra A (2018) Spectroscopy and Dipole Moment of the Molecule C13H20BeLi2SeSi via Quantum Chemistry Using Ab Initio, Hartree-Fock Method in the Base Set CCpVTZ and 6-311G**(3df, 3pd). American Journal of Quantum Chemistry and Molecular Spectroscopy 2(1): 9-17.

70. Gobato R, Gobato MRR, Heidari A (2019) Raman Spectroscopy Study of the Nano Molecule C13H20BeLi2SeSi Using ab initio and HartreeFock Methods in the Basis Set CC-pVTZ and 6-311G** (3df, 3pd). International Journal of Advanced Engineering and Science7(1): 14-35.

71. Heidari A, Gobato R (2019) Evaluating the Effect of Anti-Cancer Nano Drugs Dosage and Reduced Leukemia and Polycythemia Vera Levels on Trend of the Human Blood and Bone Marrow Cancers under Synchrotron Radiation. Trends in Res 2 (1): 1-8.

72. Heidari A, Gobato R (2019) Assessing the Variety of Synchrotron, Synchrocyclotron and LASER Radiations and Their Roles and Applications in Human Cancer Cells, Tissues and Tumors Diagnosis and Treatment.Trends in Res, Volume 2 (1): 1-8.

73. Heidari A, Gobato R (2019) Pros and Cons Controversy on Malignant Human Cancer Cells, Tissues and Tumors Transformation Process to Benign Human Cancer Cells, Tissues and Tumors. Trends in Res 2 (1): 1-8.

74. Heidari A, Gobato R (2019) Three-Dimensional (3D) Simulations of Human Cancer Cells, Tissues and Tumors for Using in Human Cancer 
Cells, Tissues and Tumors Diagnosis and Treatment as a Powerful Tool in Human Cancer Cells, Tissues and Tumors Research and Anti-Cancer Nano Drugs Sensitivity and Delivery Area Discovery and Evaluation. Trends in Res, Volume 2(1): 1-8.

75. Heidari A, Gobato R (2019) Investigation of Energy Production by Synchrotron, Synchrocyclotron and LASER Radiations in Human Cancer Cells, Tissues and Tumors and Evaluation of Their Effective on Human Cancer Cells, Tissues and Tumors Treatment Trend. Trends in Res 2 (1): $1-8$

76. Heidari A, Gobato R (2019) High-Resolution Mapping of DNA/RNA Hypermethylation and Hypomethylation Process in Human Cancer Cells, Tissues and Tumors under Synchrotron Radiation. Trends in Res 2(2): $1-9$

77. Gobato R,Gobato MRR, Heidari A (2019) Storm Vortex in the Center of Paraná State on June 6, 2017: A Case Study. Sumerianz Journal of Scientific Research 2(2): 24-31.

78. Gobato R, Gobato MRR, Heidari A(2019) Attenuated Total ReflectionFourier Transform Infrared (ATR-FTIR) Spectroscopy Study of the Nano Molecule C13H20BeLi2SeSi Using ab initio and Hartree-Fock Methods in the Basis Set RHF/CC- pVTZ and RHF/6-311G** (3df, 3pd): An Experimental Challenge to Chemists. Chemistry Reports 2(1): 1-26.

79. Gobato R, Gobato MRR, Heidari A, Mitra A (2019) New NanoMolecule Kurumi-C13H 20BeLi2SeSi/C13H19BeLi2SeSi, and Raman Spectroscopy Using ab initio, Hartree-Fock Method in the Base Set CCpVTZ and 6-311G** (3df, 3pd). J Anal Pharm Res 8 (1): 1-6.

80. Gobato R, Gobato MRR, Heidari A (2019) Evidence of Tornado Storm Hit the Counties of Rio Branco do Ivaí and Rosario de Ivaí, Southern Brazil. Sci Lett 7 (1): 9.

81. Moharana Choudhury, Pardis Fazli, Prosenjit Pramanick, Ricardo Gobato, Sufia Zaman, et al. (2019) Sensitivity of the Indian Sundarban mangrove ecosystem to local level climate change. Parana Journal of Science and Education 5 (3): 24-28.

82. Arpita Saha, Ricardo Gobato, Sufia Zaman, Abhijit Mitra (2019) Biomass Study of Mangroves in Indian Sundarbans: A Case Study from Satjelia Island. Parana Journal of Science and Education 5(2): 1-5.

83. Nabonita Pal, Arpan Mitra, Ricardo Gobato, Sufia Zaman, Abhijit Mitra (2019) Natural Oxygen Counters in Indian Sundarbans, the Mangrove Dominated World Heritage Site. Parana Journal of Science and Education 5(2): 6-13.

84. Ricardo Gobato, Victoria Alexandrovna Kuzmicheva, Valery Borisovich Morozov (2019) Einstein's hypothesis is confirmed by the example of the Schwarzschild problem. Parana Journal of Science and Education 5 (1): 1-6.

85. Sufia Zaman, Ricardo Gobato, Prosenjit Pramanick, Pavel Biswas, Uddalok Chatterjee, et al. (2018) Water quality of the River Ganga in and around the city of Kolkata during and after Goddess Durga immersion. Parana Journal of Science and Education 4 (9): 1-7.

\section{ISSN: 2574-1241}

DOI: $10.26717 /$ BJSTR.2020.25.004152

Ricardo Gobato. Biomed J Sci \& Tech Res

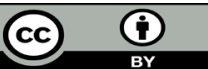

This work is licensed under Creative

Commons Attribution 4.0 License

Submission Link: https://biomedres.us/submit-manuscript.php
86. Ozan Yarman, Metin Arik, Ricardo Gobato, Tolga Yarman (2018) Clarification of Overall Relativistic Energy According to Yarman's Approach. Parana Journal of Science and Education 4(8): 1-10.

87. Sufia Zaman, Utpal Pal, Ricardo Gobato, Alekssander Gobato, Abhijit Mitra (2018) The Changing Trends of Climate in Context to Indian Sundarbans. Parana Journal of Science and Education 4(7): 24-28.

88. Suresh Kumar Agarwal, Sitangshu Roy, Prosenjit Pramanick, Prosenjit Mitra, Ricardo Gobato, et al. (2018) Parana Journal of Science and Education 4(5): 15-20.

89. Ricardo Gobato, Marcia Regina Risso Gobato (2018) Evidence of Tornadoes Reaching the Countries of Rio Branco do Ivai and Rosario de Ivai, Southern Brazil on June 6, 2017. Climatol Weather Forecasting 6: 4.

90. Ricardo Gobato (2019) New Nano-Molecule Kurumi and Raman Spectroscopy using ab initio, Hartree-Fock Method. Am J Biomed Sci \& Res 2(4). AJBSR. MS. ID. 000594.

91. Graf DL (1961) Rhodochrosite, Crystallographic tables for the rhombohedral carbonates, American Mineralogist 46: 1283-1316.

92. Maslen EN, Streltsov VA, Streltsova NR, Ishizawa N (1995) Electron density and optical anisotropy in rhombohedral carbonates. III. Synchrotron X-ray studies of $\mathrm{CaCO}_{3}, \mathrm{MgCO}_{3}$ and $\mathrm{MnCO}_{3}$, Acta Crystallographica B51: 929-939.

93. Wyckoff R (1920) The crystal structures of some carbonates of the calcite group. American Journal of Science 50: 317-360.

94. Marcus D, Hanwell DE, Curtis DC, Lonie TV, Zurek E, et al. (2012) Avogadro: An advanced semantic chemical editor, visualization, and analysis platform. Journal of Cheminformatics 4: 17 .

95. Cioslowski J (1989) General and unique partitioning of molecular electronic properties into atomic contributions. J Cioslowski, Phys Rev Lett 62: 1469.

96. Paul von Ragu Schleyer (1998) Encyclopedia of computational chemistry, New York, J Wiley.

97. Mulliken RS (1955) Electronic Population Analysis on LCAO-MO Molecular Wave Functions. I. The Journal of Chemical Physics 23 (10): 1833-1840. Bibcode: 1955 J Ch Ph. 23.1833M.

98. Stevens WJ, Basch H, Krauss M (1984) Compact effective potentials and efficient shared-exponent basis-sets for the 1st-row and 2 nd-row atoms. J Chem Phys 81: 6026-6033.

99. Stevens WJ, Krauss M, Basch H,Jasien PG (1992) Relativistic compact effective potentials and efficient, shared-exponent basis-sets for the 3rdrow, 4th-row, and 5th-row atoms. Can J Chem 70 : 612-630.

100. Cundari TR, Stevens WJ (1993) Effective core potential methods for the lanthanides. J Chem Phys 98: 5555-5565.

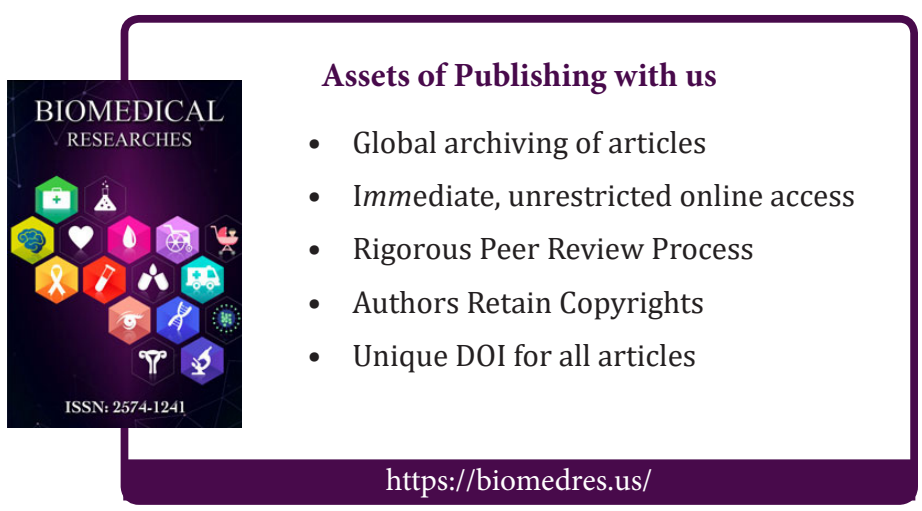

